Szabó Éva ${ }^{1}$ - Jagodics Balázs

${ }^{1}$ Szegedi Tudományegyetem Pszichológiai Intézet, Szociál- és Fejlődéspszichológiai Tanszék

${ }^{2}$ Szegedi SZC Kőrösy József Közgazdasági Szakgimnáziuma

\title{
Erőforrások és követelmények
}

\section{A tanári kiégés munkahelyi tényezöinek komplex vizsgálata}

A munkában való kifáradás, a naponta kapott újabb és újabb feladatok idönként minden ember számára azt a gondolatot vetik fel, hogy jobb lenne nem dolgozni, vagy valami egészen mást csinálni

ahelyett, amit kell. Ha azonban minden munkanap ezzel a gondolattal indul és/vagy végzódik, az már nem egyszerú fáradtság, hanem a kiégés kezdetére utaló jel is lehet. Számos hivatással együtt,

az elmúlt évtizedek alatt a pedagógusok munkája is jelentôsen

átalakult. A követelmények egyre emelkednek, ami gyakran nem párosul a munkafeltételek és az életminóség javulásával, így ezt a társadalmi csoportot is jelentôsen veszélyezteti a kiégés jelensége. A pedagógus fásultsága vagy kimerültsége azonban nem csupán személyes probléma. A diákok és a szülók életére is hatással van, hogy a tanárok milyen lelkesedéssel végzik a munkájukat.

A pedagógusoktól elvárt magas hivatástudat és a gyakran kritikus társadalmi megitélés is szerepet játszhat abban, hogy ezen a területen viszonylag kevés hazai vizsgálatról olvashattunk az elmúlt évtizedekben. A probléma azonban jelen van, és a tudomány

feladata, hogy minél mélyebben feltárja a kiégés-szindróma

természetét és múködését, hogy hozzásegitse a szakembereket a megelózéshez és a probléma megoldásához szükséges ismeretekhez.

\section{A kiégés-szindróma kialakulása, jellemzői}

A munkahelyi élmények egyéni mentálhigiénés állapotra gyakorolt hatásának feltárására a huszadik század utolsó időszakában került a pszichológiai kutatások homlokterébe. A „,burnout-szindróma” fogalmának meghatározása és a tünetcsoport első leírása a kórházi személyzet pszichológiai terhelésének vizsgálatához kapcsolódott. Freudenberger (1974) megfigyelései szerint a kiégés-szindrómában szenvedő egyéneket gyakran gyötri fáradtság és kimerültség, könnyen betegszenek meg, fejfájástól, emésztési problémáktól és alvási zavaroktól szenvednek. Emellett jellegzetes, érzelmileg túlfütött reakciókat mutatnak: frusztráltnak, ingerültnek tünnek, gyakoriak náluk az impulzív válaszok. A kiégés-szindrómában szenvedők kevésbé toleránsak a nehézségeket okozó helyzetekkel szemben, türelmetlenebbek, jellemző rájuk a negatív hozzáállás és a cinikus reagálási módok, melyek a közvetlen környezetük számára is nehézzé teszik a helyzet kezelését (Maslach és Goldberg, 1998). 
A Freudenberger (1974) által leírt állapot többek között abban különbözik más szorongásos problémáktól és a depressziótól, hogy a tünetek kialakulásában elsődlegesen a munkahelyi tényezők játszanak szerepet. A burnout-szindróma kialakulásában jelentős tényező a munkahelyen tapasztalt folyamatos és nagymértékủ stressz, amely hosszú távon megterheli a személyt, legyőzi belső erőforrásait és védekezőképességét, így kialakul a jellegzetes tünetegyüttes, amelyet összefoglaló néven kiégésnek nevezünk (Hare, Pritt és Andrews, 1988).

A munkahelyi leterheltséggel összefüggő burnout-szindróma afféle ördögi körré alakul, tekintve hogy egyik fontos következménye, hogy a személy lehangoltságának és a motiválatlanságnak következtében a munkavégzés hatékonysága csökken, a személy egyre elégedetlenebb lesz önmagával és munkájával, ami tovább fokozza az átélt stresszt. Ez a kellemetlen érzés fokozott elkerülő viselkedést vált ki, azaz a kiégés tüneteitől szenvedő munkavállaló gyakrabban jelent indokolatlanul beteget, és többé-kevésbé szándékosan marad távol a munkahelytől, ami tovább rontja a munkavégzés hatékonyságát, sőt egzisztenciálisan is veszélybe sodorhatja a munkavállalót (Bakker, Demerouti, de Boer és Schaufeli, 2003). A munkahelyi hatékonyság csökkenése a legtöbb kiégésmodell központi eleme. A legismertebb elmélet, amely Maslach nevéhez füződik, három fö tünetcsoportot különít el, melyek közül az első a munkahelyi hatékonysággal összefüggő személyesteljesítmény-csökkenés, a második az érzelmi kimerülés, a harmadik pedig a társas közegtől való eltávolodást jelző deperszonalizáció (Maslach, 1982).

\section{Munkahelyi tényezők szerepe a kiégés kialakulásában}

Freudenberger (1974) elsőként a kórházi dolgozók problémájaként írta le a kiégés-szindrómát, azonban a kutatások számos más hivatást is azonosítottak, amelyek fokozott veszélyt jelentenek a jelenség kialakulásának szempontjából. Kezdetben a kutatások ezek közös jellemzőit keresték, és megállapították, hogy a humán területen, nagy érzelmi teherrel járó munkák azok, amelyek leginkább okozhatnak kiégést (Price és Murphy, 1984). Ennek megfelelően az egészségügyi dolgozók mellett más segítő foglalkozást végző személyeknél (pszichológusok, szociális munkások) vagy az oktatásban dolgozók között is beszélhetünk kiégésről. Későbbi kutatások kiemelték az erős mentális terhelés szerepét, így már olyan foglalkozások is bekerültek a kutatók látókörébe, amelyeknek nem elsődleges jellemzője, hogy emberekkel kell foglalkozni, mint például a légi irányítók, laboratóriumi dolgozók vagy a szerelőmunkások csoportja (Demerouti, Bakker, Nahreiner és Schaufeli, 2001).

A munka tárgya és jellemzői mellett egyre nagyobb figyelem irányult a munkavégzés pszichológiai körülményeire is, mint a kiégés megjelenését befolyásoló tényezőkre. Ilyen meghatározó sajátosságnak bizonyult a munkahelyi klíma (Schein, 1997). A pozitív munkahelyi klíma védőfaktorként szerepel a kiégés szempontjából, mert képes elősegíteni az egyéni fejlödést, valamint kedvező hatással van a személyek közötti kapcsolatokra is (Ceyda és Sevinc, 2012). A munkahelyi légkör fontos összetevője a társas támogatás, amelyet munkatársaktól és felettesek irányából kaphat a munkavállaló. A pozitív társas interakciók (Brouwers, Tomic és Boluijt, 2011), valamint a konkrét feladatok megoldásában nyújtott segítség (Glass és McKnight, 1996) elősegíti a kiégés-szindróma kialakulásának megelőzését. A szakmai segítségnyújtás mellett sikerült bizonyítani a munkahelyen megélt érzelmi támasz, együttérzés preventív szerepét is (Glass és McKnight, 1996). A szervezet mérete is befolyást gyakorol a szervezeti klímára. Tanári közösségek vizsgálatának eredményei szerint minél nagyobb létszámú a szervezet, annál kevésbé érzik kollégáik támogatását a közösség tagjai (Skaalvik és Skaalvik, 2009). 
Szabó Éva - Jagodics Balázs: Erőforrások és követelmények

Az eddigiekben áttekintett kiégéssel kapcsolatos kutatások rámutattak a munka és szervezeti jellemzők hatására, ugyanakkor adósak maradtak a pozitív és negatív tényezők együttes hatásának elemzésével.

\section{A munkahelyi követelmények és eröforrások kapcsolata}

A kiégés-szindróma kialakulásával összefüggésbe hozható munkahelyi tényezők két csoportba oszthatók. Az egyik csoportba az erőforrások, a másikba a követelmények tartoznak (Demerouti, Bakker, Nahreiner és Schaufeli, 2001). Míg elöbbiek elősegítik, hogy a munkavállalók terhei csökkenjenek és a feladatok elvégzése során sikeresek legyenek, addig a követelmények különböző módon növelik a dolgozók leterheltségét, illetve az őket érő stresszt és az átélt szorongás mértékét. A kutatások eredményei szerint a burnout-szindróma kialakulásának valószínüsége akkor nő meg leginkább, ha az erőforrások nem állnak arányban a leterheltséget okozó tényezőkkel (Maslach és Goldberg, 1998).

Ezt az elképzelést elsöként Karasek (1979) vetette fel követelmény-kontroll (demand-controll) modelljében. Elmélete szerint a munkahelyen tapasztalt stresszt a túlterheltség vagy az időhiány okozza, amelynek elviselését és kezelését jelentősen befolyásolja, hogy a dolgozók mekkora szabadságot és kontrollt éreznek saját munkavégzésük felett. A későbbi kutatások, Karasek (1979) elméletéből kiindulva további munkahelyi tényezőket azonosítottak, amelyek beilleszthetők az erőforrások és a követelmények rendszerébe.

Az egyik legátfogóbb Demerouti és munkatársai (2001) munkahelyi követelmény-erőforrás modellje (job demands and resources model), amelyben a munkahelyi követelmények közé soroltak minden olyan környezeti, társas vagy szervezeti tényezőt, amelynek kezelése a munkavégzés során fizikai, érzelmi vagy mentális erőfeszítést igényel a munkavállaló részéröl, ezáltal akár testi, akár pszichológiai értelemben fáradtságot okoznak (Demerouti és mtsai, 2001). Ilyen körülmény lehet a fokozottan fárasztó fizikai vagy szellemi munka, a szoros határidők, az érzelmileg megterhelö helyzetek és kapcsolatok mint például a pedagógusok esetében a diákok rendbontó viselkedése -, de idesorolhatók a munka jellegéböl adódó kellemetlenségek, mint például a magas zajszint, vagy a váltott müszakban való munkavégzés (Hakanen, Bakker és Schaufeli, 2006; Demerouti és mtsai, 2001). Az erőforrások csoportjába tartoznak a munkahely azon jellemzői, amelyek elősegítik a követelmények teljesítését, illetve biztosítják annak feltételeit, azzal, hogy megvalósíthatóvá teszik a munkahelyi célokat, csökkentik a fizikai vagy pszichológiai kimerültséget, és hozzájárulnak a munkavállaló személyes fejlődéséhez, illetve jóllétéhez (Demerouti és $m t s a i, 2001)$. Ilyen erőforrást jelentő tényező lehet a Karasek (1979) modelljében is megjelenő munkavégzés feletti kontroll, továbbá a döntéshozatalban való részvétel lehetősége, a felettesek felől érkező támogatás, a megbízható jutalmazások és visszajelzések rendszere, a szupervíziós támogatás, a továbbképzési és szakmai fejlődési lehetőségek, a munkatársak szakmai és érzelmi társas támogatása, illetve a munkahely stabilitása, biztonsága és kiszámíthatósága. Az erőforrások hiánya vagy jelentős csökkenése negatívan hat a munkavállalók elköteleződésére, leépíti a közös célok elérésével kapcsolatos motivációt, és fokozza a testi és érzelmi kimerülést (Demerouti és $m t s a i, 2001$ ).

\section{Pedagógus pálya és kiégés}

A tapasztalatok és a vizsgálati eredmények egyaránt azt mutatják, hogy a pedagógus pályán dolgozók erősen veszélyeztetett csoport a kiégés-szindróma kialakulásának szempontjából. Egy finn kutatásban azt találták, hogy a tanárok között volt a kiégés-szindróma 
aránya a legmagasabb, összehasonlítva más humán szférába tartozó foglalkozásokkal (Kalimo és Hakanen, 2000; idézi: Hakanen, Bakker és Schaufeli, 2006), amely legerőteljesebben a cinikussá váló beszédstílusban nyilvánult meg. A cinizmus fokozott kialakulását más vizsgálatok eredményei is megerősítették (Maslach, Jackson és Leiter, 1996), de igen jellemző az emocionális tünetek és a pedagógusok érzelmi kimerülésének megjelenése is (Tanham és Can, 2011). A probléma súlyosságát jelzik Farber (1991; idézi Hakanen, Bakker és Schaufeli, 2006) vizsgálati eredményei is, melyek szerint az Amerikai Egyesült Államokban a pedagógusok 5-20\%-át érintik a kiégés tünetei. Nemcsak a közoktatásban, de a felsőoktatásban dolgozók körében is jelentkezik a kiégés problémája. Az egyetemi oktatókat érintő kutatások szerint mintegy negyedük a kiégés érzelmi tüneteitől szenved, 20\%-uk személyes hatékonyságuk tekintetében tekinthető érintettnek, míg 10\%-uknál elsősorban a társas elidegenedés figyelhető meg (Lackritz, 2004).

Jóllehet a tanári munka nem tartozik a klasszikus segítő foglalkozások közé, mégis számos olyan jellemzője van, amely elősegíti a kiégés-szindróma kialakulását. Ezek közül is kiemelkedik a munka mennyisége által okozott mentális terhelés (Demerouti és mtsai, 2001), hiszen az órákra való felkészülés és az azokon való részvétel sok munkát, folyamatos figyelmet, és állandó készenlétet igényel. A munkahelyi terhelést tovább növeli, ha magas tanulói létszámmal, illetve magas óraszámmal kell dolgoznia a pedagógusoknak. A felsőoktatásban dolgozó oktatók kiégés-tüneteinek előfordulása szintén összefüggésben áll a kurzusaikon részt vevő hallgatók számával, valamint a felkészüléshez szükséges idővel (Lackritz, 2004).

A túlterheltség mellett az is fokozza a kiégés veszélyét, hogy a tanári pályán gyakran jellemző a hatékony munkavégzéshez szükséges eszközök egy részének hiánya vagy nem megfelelő minősége (Fernet, Guay, Senécal és Austin, 2012). Egy további kiégést okozó tényező, hogy a pedagógus pályán számos helyzetben élnek át szerepkonfliktust a tanárok, hiszen a támogató-facilitáló, valamint az értékelö-ellenőrző szerepek párhuzamosan vannak jelen a munkában, és ezek megfelelö betöltése sok esetben összeegyeztethetetlen követelményeket támaszt a tanárral szemben. Mindezek mellett sajnos az is gyakori, hogy a tanári közösségekben a munkahelyi klíma nem kedvez a pozitív emberi kapcsolatoknak, a társas támogatás sok esetben hiányzik, és a kapcsolatok megoldatlan konfliktusokkal terheltek (Fernet, Guay, Senécal és Austin, 2012). A kutatások tanúsága szerint elöfordult, hogy a negatív klíma, akár a munkahelyi zaklatás megjelenéséhez is vezetett (Tanham és Cam, 2011). Ezek a hatások együttesen csökkentik azokat az eröforrásokat, amelyek segítenék a pedagógusokat abban, hogy sikeresen feleljenek meg a munkahelyi követelményeknek. Ha ezekhez még hozzávesszük az adminisztrációs terheket és a korlátozott szakmai fejlődési lehetőségeket, akkor nyilvánvaló, hogy az iskolákban gyakran felborul a követelmények és az erőforrások egyensúlya, ami a kiégéshez vezet (Demerouti és mtsai, 2001; Fernet, Guay, Senécal és Austin, 2012). A pedagógusok észlelt leterheltsége, vagyis a követelmények túlsúlya bejósolja a burnout-szindróma tüneteinek súlyosságát, míg az erőforrások elérhetősége csökkenti azokat (Hakanen, Bakker és Schaufeli, 2006).

A hazai pedagógusok kiégettségi állapotáról viszonylag kevés átfogó vizsgálat készült. A rendszerváltás előtti időszakban ez a kérdés, sok más témához hasonlóan tabunak számított. Az első ilyen jellegü kutatások a 90-es években kezdődtek. Petróczi és munkatársai (2007) átfogó munkájukban rámutattak a problémára, és felvillantották lehetséges prevenciós lépéseket.

A pedagógusok általános „közérzetét” feltáró legfrissebb kutatás (Paksi és mtsai, 2015) sok más tényező mellett vizsgálat tárgyává tette a kiégés jelenségét is. A pedagóguspályával kapcsolatos vélekedéseket és tapasztalatokat feltáró kérdőíves vizsgálat 3485 végzős középiskolás, 1220 egyetemi hallgató, 1078 gyakorló pedagógus és 40 pályáját elhagyó pedagógus válaszainak elemzését tárja a tudományos közvélemény elé. 
Az átfogó kutatás eredményei szerint a pedagógus pálya megbecsültsége mind társadalmi, mind pedig anyagi szempontból alatta marad más diplomás foglalkozások elismertségének. Ezzel szemben a pedagógus foglalkozást a munka-magánélet egyensúly, illetve az önmegvalósítás lehetősége szempontjából az átlagosnál kedvezőbb hivatásának látják mind a szakmabeli, mind a szakmán kívüli válaszadók. A kutatásban a kiégés feltárására a Maslach Burnout Inventory önbeszámolós kérdöívét használták. Az eredmények rámutattak, hogy az érzelmi kimerültség tekintetében érintettek leginkább a pedagógusok, amelyet a személyes teljesítmény csökkenése, illetve a deperszonalizáció követ. Az alkalmazott viszonyítási ponttól függően, a kutatás szerint a pedagógusok mintegy 5-8\%-a tekinthető kiégettnek. A kutatás tanulsága szerint védőfaktornak tekinthető a nagyobb szakmai tapasztalat, a kielégítő munkahelyi és a magánéleti kapcsolatok megléte, az intézmény iránti elköteleződés, illetve a szakmai továbbképzéseken való részvétel.

A pedagógusok kiégettsége egyrészt személyes, másrészt azonban szervezeti, sőt társadalmi probléma is, hiszen a kiégettség amellett, hogy rontja az egyén életminőségét, jelentősen kihat a munkavégzésre is. Ez a pedagógusok esetében azt jelenti, hogy számos gyerek iskolai élményeit negatívan befolyásolhatja. Kutatások bizonyítják, hogy ha a diákok kiégettnek észlelik pedagógusaikat, akkor maguk is motiválatlanabbak lesznek (Tatar, Yahav, 1999), gyakrabban követnek el iskolai csalást a számonkérések esetén (Orosz és Karsai, 2012). A korábban bemutatott hazai felmérés a tanárok 5-8\%-ánál állapította meg a kiégés jeleit (Paksi és mtsai, 2015). Ez a szám önmagában is elég magas. Különö-

A pedagógusok kiégettsége egyrészt személyes, másrészt azonban szervezeti, sót társadalmi probléma is, hiszen a kiégettség amellett, hogy rontja az egyén életminóségét, jelentôsen kihat a munkavégzésre is. Ez a pedagógusok esetében azt jelenti, hogy számos gyerek iskolai élményeit negativan befolyásolhatja. Kutatások bizonyitják, hogy ha a diákok kiégettnek észlelik pedagógusaikat, akkor maguk is motiválatlanabbak lesznek (Tatar, Yahav, 1999), gyakrabban követnek el iskolai csalást a számonkérések esetén (Orosz és Karsai, 2012). sen akkor, ha figyelembe vesszük, hogy az önkitöltős kérdőíves módszer esetében számolnunk kell a szociális kívánatosság hatásával is, azaz feltételezhetjük, hogy ennél az értéknél a valóságban magasabb számban lehetnek kiégési problémával küzdő tanárok. A munkavégzés hatékonyságát tovább csökkenti, hogy a kiégés-szindróma által nagyobb mértékben érintett tanárokat kevésbé motiválja saját szakmai fejlődésük, ami stagnálást eredményezhet egy olyan munkahelyen, ahol nap mint nap új kihívásokkal kell szembenézni (Özer és Beycioglu, 2010).

A tavalyi tanévben Paksi és munkatársai (2015) által végzett átfogó kutatásnak elsősorban az volt a célja, hogy rámutasson a problémára, és feltárja néhány összetevőjét, kiemelt figyelmet szentelve a szervezeti szempontoknak, amelyek a korábbi kutatásokban eddig kisebb hangsúlyt kaptak. Jelen kutatás célja, hogy megvizsgálja a szervezetpszichológiai gyökerü követelmény-eröforrás modell (Demerouti és mtsai, 2001) érvényességét pedagógusok mintáján. Feltárja, hogy a kiégés a követelmények és az erőforrások mely elemeivel van legerősebb kapcsolatban, valamint hogy ezek aránya miként viszonyul a kiégés megjelenéséhez. 


\section{Kérdések, hipotézisek}

Kutatásunk elsődleges célja egy elméleti modell (Demerouti és mtsai, 2001) érvényességének tesztelése, az általunk kialakított, illetve adaptált vizsgáló eljárások segítségével. Ennek megfelelően feltételezzük, hogy a pedagógusok kiégésének mértékét is befolyásolják a munkahelyi tényezők, azon belül is az erőforrások és elvárások közötti különbség. Feltételezzük, hogy a munkahelyi erőforrások protektív faktorként müködnek, ennek megfelelően negatív korrelációt mutatnak a kiégés összpontszámmal, míg a munkahelyi követelmények és a kiégés pontszám között pozitív korrelációt várunk.

Az elméleti modellből kiindulva feltételeztük továbbá, hogy a követelmények és erőforrások nemcsak külön-külön vannak kapcsolatban a kiégéssel, de ami igazán jelentős hatást gyakorol a kiégésre az a kettő közötti különbség. Ezért hoztuk létre az ún. leterheltségmutatót, amely az erőforrások és követelmények különbségéböl adódik. Feltételeztük, hogy a leterheltségmutató és a kiégés összpontszám között pozitív korreláció áll fenn. A változók kiégés pontszámra gyakorolt hatását regresszióelemzéssel ellenőrizzük.

A kutatás további kérdése volt számunkra, hogy van-e bármilyen hatása a kiégés mértékére az iskolatípusnak, amelyben a pedagógus dolgozik. A korábbi kutatások a különböző demográfiai jellemzőkkel kapcsolatban ellentmondásos eredményeket hoztak, így konkrét előfeltevéssel e tekintetben nem éltünk, csupán feltáró jelleggel vetettük fel ezt a kérdést.

\section{Alkalmazott módszerek}

\section{Kiégés-kérdöív}

A burnout-szindróma tüneteit a Maslach-féle kiégés kérdőív tanári munkára specializált változatának hazai adaptációjával mértük (Hennig és Keller, 1995). A kérdőív négy alskálán osztályozza a tüneteket, amelyek hat-hat tételből állnak: a kérdőív a kiégés lelki, érzelmi, szociális és testi szimptómáinak meglétét értékeli. Az eredetileg 24 tételből álló kérdőív magyar változatát alkalmasnak találtuk a probléma feltárására (Jagodics és Szabó, 2014). A mérőeszköz kipróbálása óta eltelt idő alatt összegyülő adatok alapján az SPSS szoftver AMOS programjával újra elvégeztük a kérdőív faktorstruktúrájának megerősítő faktorelemzését. A lényegesen nagyobb mintán $(\mathrm{N}=1040)$ végzett elemzés rámutatott arra, hogy a skála egyes itemeinek kihagyása jelentősen javítja az illeszkedést. Az így kialakult skála szintén négy alskálából áll, de ezek a korábbi hat tétel helyett már csupán négy-négy itemet tartalmaznak. A megerösítő faktorelezmzés mutatói minden tekintetben megfelelnek a követelményeknek $(\mathrm{N}=1043$ fö, Chi négyzet/Szabadságfok $=5,171, \mathrm{CFI}=0,945$, TLI $=0,929 ; \mathrm{RMR}=0,035 ; \mathrm{RMSEA}=0,063)$. A jóságmutatók értékelése során a Scheiber és munkatársai (2006) által meghatározott határértékeket használtuk. A korábbi kutatások során kapott ellentmondásos eredmények miatt (Jagodics és Szabó, 2014; Ahola és Hakanen, 2014) a testi kiégés alskála pontszámait jelen kutatásban nem értelmezzük. Ezt részben az is indokolja, hogy a testi tünetek megjelenése nemcsak a kiégéshez kötődhet, más életmódbeli jellemzőkkel is összefügghet. Így a kutatásban használt kiégés kérdőív három alskálából állt, amelyek négy-négy tételből épülnek fel. A három alskála az eredetihez hasonlóan: a kiégés lelki (Cronbach $\alpha=0,668$; pl. ,, Gondolkozom rajta, hogy elhagyom a pedagógus pályát”), érzelmi (Cronbach $\alpha=0,778$; pl.: „, Gyakran nyugtalannak és idegesnek érzem magam”) és társas tüneteit méri (Cronbach $\alpha=0,613$; pl.: „Elzárkózom attól, hogy a problémás tanulóknak segitsek"). A válaszadás 0-4-ig terjedő Likert-skálán történt. Egy-egy alskálán maximálisan 16 pont érhető el. Az összegző skálatechnikának köszönhetően az alskálákon jelölt pontértékek összegeként meghatározható a kiégés-stressz fogékonyság mutatója, amelynek értéke maximálisan 48 pont lehet. 


\section{Munkahelyi követelmények és erőforrások kérdőiv}

A munkahelyen rendelkezésre álló erőforrásokat és felmerülő követelményeket saját fejlesztésű kérdőívvel mértük (Jagodics és Szabó, 2014). Az erőforrásokat feltáró rész összesen négy alskálát tartalmaz. Az első, a munkavégzés feletti kontroll (Cronbach $\alpha=$ 0,75; pl.: „A munkám során eldönthetem, hogyan oldom meg a feladataimat”), a második, a felettestől érkező támogatás (Cronbach $\alpha=0,93$; pl.: „,Ha szükséges, kérhetek segítséget a felettesemtoll"). A harmadik, személyes fejlődés lehetősége (Cronbach $\alpha=0,73$; pl.: „, A munkám lehetöségeket biztosit, hogy szakmailag fejlödjek”), és végül a negyedik, a munkavégzéshez szükséges információk és visszajelzések megléte (Cronbach $\alpha=0,79$; pl.:,, A munkám során elég visszajelzést kapok az elvégzett feladataimról”). A követelményeket feltáró rész szintén négy alskálából áll. Ezek az érzelmi követelmények (Cronbach $\alpha=0,78$; pl.: „A munkám során olyan helyzetekbe kerülök, amelyek érzelmileg felzaklatnak”), a mentális leterheltség tényezői (Cronbach $\alpha=0,70 ; \mathrm{pl} .:$ „A munkám során több dologra kell egyszerre figyelnem "), a munkamódból fakadó követelmények (Cronbach $\alpha$ =0,87; pl.: „Egyszerre nagyon sok munkát kell elvégeznem”) és interperszonális konfliktusok (Cronbach $\alpha=0,53$, pl.: ,Sok konfliktusom van a kollégáimmal”). Látható, hogy a konfliktusokra vonatkozó alsákla esetében nagyon alacsony reliabilitás mutatót kaptunk. Vélhetően ezek a tételek nem mindenki számára jelentették ugyanazt. A kérdőív tételeire ötfokozatú Likert-skálán adnak választ a kitöltők, egytől ötig kifejezve egyetértésüket az állítások tartalmával. A kérdőív alskálái három-három tételből állnak. A mérőeszköz kipróbálása (Jagodics és Szabó, 2014) óta eltelt idő alatt összegyűlő adatok segítségével újra elvégeztük a kérdőív faktorstruktúrájának elemzését. Az SPSS AMOS programja segítségével elvégzett megerősítő faktorelemzés eredményeként kapott adatok alapján a jobb illeszkedési mutatók miatt az eredeti hat item helyett négy tételből álló alskálákat hoztunk létre $(\mathrm{N}=664$ fó, Chi négyzet/Szabadságfok $=3,673 ; \mathrm{CFI}=0,967$; TLI = 0,954; $\mathrm{RMR}=0,5 ; \mathrm{RMSEA}=0,63$. A jóságmutatók értékelése során a Scheiber és munkatársai [2006] által meghatározott határértékeket használtuk).

Az alskálák összesített pontszámának kiszámításán túl fontos szerepe van az elemzésekben a leterheltség mutatónak, amely a követelmények és az erőforrások pontszámainak különbségeként határozható meg. A leterheltségmutató azt fejezi ki, hogy a két ellentétes hatású munkahelyi tényező közül melyik kerül túlsúlyba. Amennyiben a leterheltségpontszám pozitív, akkor a követelmények hangsúlya jellemző, ha viszont negatív előjelü az érték, akkor az erőforrások kerülnek túlsúlyba.

A kérdőív első részében néhány demográfiai adat megadását kértük a kitöltőktől: nem; életkor; tanítási tapasztalat; a település típusa, ahol tanít; intézmény típusa, ahol tanít. Utóbbi esetében a válaszlehetőségek közül (általános iskola alsó tagozat, általános iskola felső tagozat, szakiskola, szakközépiskola, gimnázium) több válasz megjelölése is engedélyezett volt. Mivel a kutatás a 2015/2016-os tanévben zajlott, a szakgimnáziumok és szakközépiskolák esetében az ekkor érvényes megnevezést használtuk (szakközépiskolák, illetve szakiskolák).

\section{Vizsgálati eljárás}

A kutatást online felületen kitölthető, az Egyetemközi Pszichológiai Kutatásetikai Bizottság (EPKEB) által felülvizsgált és engedélyezett kérdőívvel végeztük. A résztvevők toborzásában kétféle módon jártunk el. Egyrészt iskolapszichológusok segítségével juttattuk el a kérdőíveket az iskolák tantestületeihez. Másrészt az Oktatási Hivatal online felületén elérhető nyilvános adatbázisból választottunk ki véletlenszerüen közoktatási intézményeket, amelyek tantestületét a megadott kapcsolattartó e-mail címen keresztül elektronikus levélben kértünk fel a vizsgálatban való részvételre. A kérdőívek kitöltése 
minden esetben anonim volt. A pedagógusok a kutatásban való részvételért semmilyen jutalmat nem kaptak. Ugyanakkor biztosítottuk, hogy a kérdőív kitöltése után a résztvevő azonnali visszajelzést kapjon a kiégés kérdőív eredményéről, amelyben az elért pontszámának megfelelően javaslatokat is kaphatott az esetleges prevenciós, intervenciós lehetőségekkel kapcsolatban. Az értékelő visszajelzés szövegét és a hozzá kapcsolódó ponthatárokat korábbi kutatási eredmények alapján (Jagodics és Szabó, 2014), valamint a szakirodalmi háttér ajánlásait, illetve saját és kollégáink iskolapszichológusi tapasztalatait figyelembe véve állítottuk össze. Emellett minden résztvevőnek lehetősége volt arra, hogy röviden értékelje a kérdöívet, valamint hogy megadjon egy jeligét a kérdőív kitöltése során, amelyre hivatkozva a megadott elektronikus levelezési címen további tájékoztatást kérhetett eredményeivel kapcsolatban, illetve kérdéseket tehetett fel a vizsgálat vezetőjének. A beérkező visszajelzések szerint a kitöltők hasznosnak és kielégítőnek találták az online kérdöív kitöltése után olvasott egyéni visszajelző szövegeket. A kitöltés átlagosan 15 percet vett igénybe.

A vizsgálatban összesen 337 pedagógus vett részt (267 nő és 70 férfi, $M_{\text {életkor }}=46,75$ év; szórás $=9,54$ év; átlagos tanítási tapasztalat $=21,55$ év; szórás $=10,93$ év).

\section{Eredmények}

Az adatok elemzését az SPSS for Windows 20.0 statisztikai programcsomaggal végeztük el. Elsőként az egyes kérdőívek eredményeit mutatjuk be, majd rátérünk a változók egymással való kapcsolatainak bemutatására. A regresszióelemzést ENTER módszerrel végeztük.

\section{A kiégés mértéke és jellemzői a vizsgált csoportban}

A teljes minta adatait figyelembe véve $(\mathrm{N}=327)$ a kiégéskérdőív három alskálája közül az érzelmi tünetek átlagpontszáma volt a legmagasabb $(\mathrm{M}=6,62$ pont; szórás $=2,9$ pont), melyet a lelki $(\mathrm{M}=4,78$ pont; szórás $=2,63$ pont $)$ és a társas $(\mathrm{M}=3,24$ pont; szórás $=2,43$ pont) területek követtek. A három terület együttes eredményét jelző összesített kiégés pontszám átlaga 14,64 pont volt a lehetséges 48 pontból (szórás $=6,8$ pont; lásd 1. ábra)

Az adatok elemzése során választ kerestünk arra a kérdésre, hogy eltérő mértékben érintik-e a kiégés tünetei a különböző oktatási intézménytípusokban dolgozó pedagógusokat. Az egyszempontos variancianalízis szerint statisztikailag szignifikáns mértékü eltérés tapasztalható az egyes intézménytípusok között a kiégés összesített pontszám mértékében $(\mathrm{F}(7 ; 329)=2,312 ; \mathrm{p}=0,026)$. A legnagyobb mértékben a szakközépiskolában tanítókat érintette a kiégés $(\mathrm{N}=50, \mathrm{M}=16,88$ pont), akikhez hasonló pontszámokat értek el a több különböző középiskola típusban is dolgozó tanárok $(\mathrm{N}=31, \mathrm{M}=16,25)$. A részletes eredményeket lásd 2 . ábra. 
Szabó Éva - Jagodics Balázs: Erőforrások és követelmények

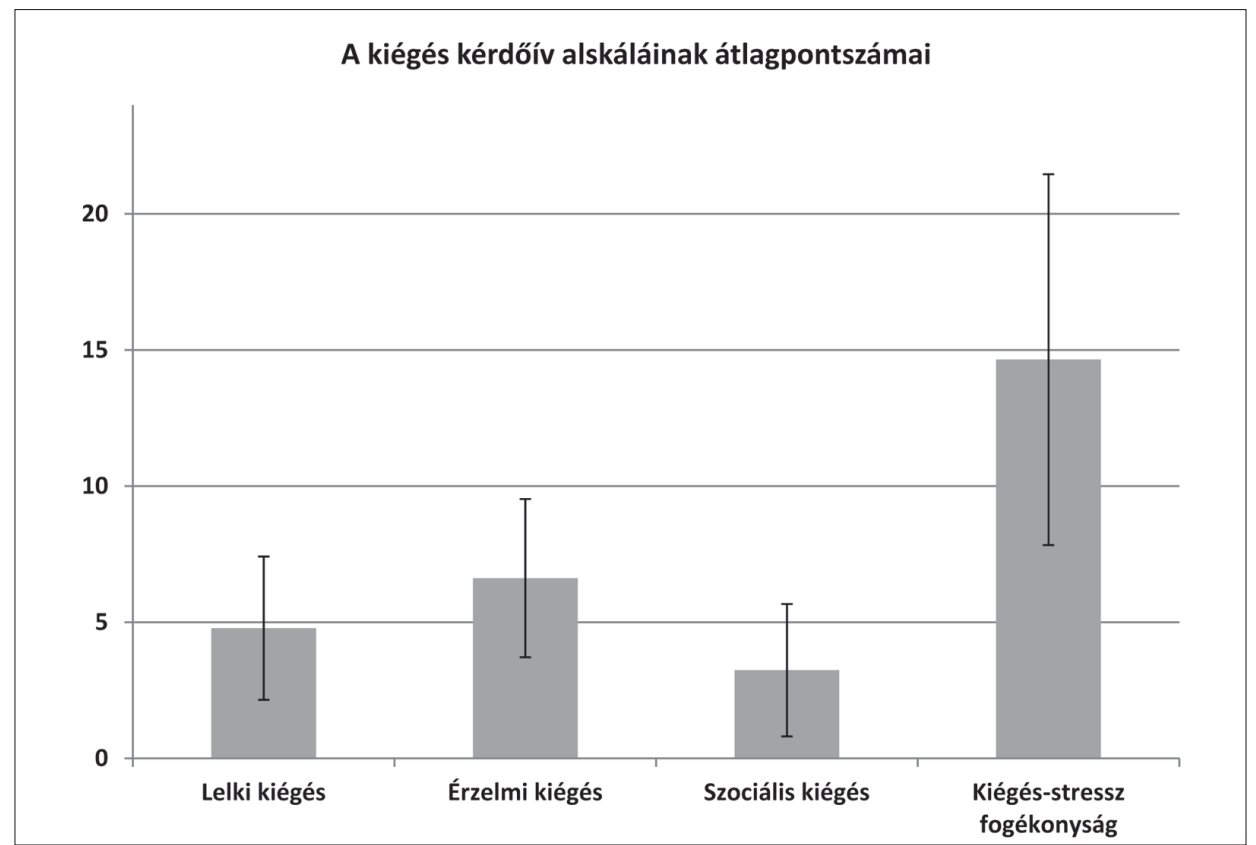

1. ábra. A kiégés kérdöiv alskáláinak és összpontszámának átlagértékei $(N=327)$

\section{A kiégés összesített pontszám átlagai a különböző intézménytípusokban}

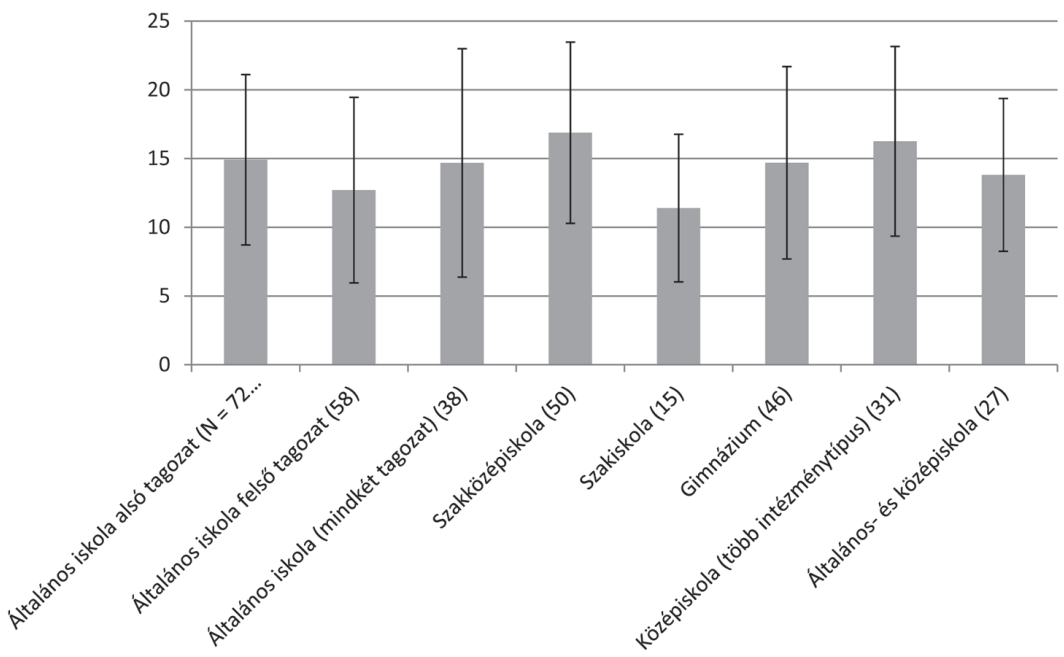

2. ábra. A kiégés kérdöiv összesitett pontszámai a különbözö típusú intézményekben.

Látható, hogy a szakközépiskolás pedagógusok érintettek a legnagyobb mértékben, míg a szakiskolások, illetve az általános iskola alsó tagozata esetében a legalacsonyabbak a pontszámok. (A zárójelben az alminták elemszámait tüntettük fel.) 


\section{Munkahelyi eröforrások és követelmények}

A szervezeti követelményeket és erőforrást jelentő tényezők kapcsolatát a kiégéssel Pearson-féle korrelációelemzéssel vizsgáltuk. Az eredmények megerősítették a követelmény-erőforrás modell alapján felállított hipotéziseket. Az erőforrások statisztikailag szignifikáns mértékủ negatív, míg a követelmények pozitív együttjárást mutatnak a kiégés pontszámokkal. Az előzetes feltételezéseknek megfelelően a leterheltség pontszám, vagyis a követelmények és erőforrások különbsége nagyobb mértékü együttjárást mutat a kiégés mértékével, mint a tényezők külön-külön (lásd 1. táblázat).

1. táblázat. A táblázatban a kiégés kérdöiv, illetve a munkahelyi követelmények és eröforrások kérdöiv alskáláinak átlagpontszámai közötti korrelációelemzések együtthatói láthatók ( $N=337$; a feltüntetett értékek minden estben szignifikánsak: $p<0,05$, kivéve az $N$. Sz. jelzésü eredményeket, ahol $p>0,05)$.

\begin{tabular}{|c|c|c|c|c|c|}
\hline & Alskála & $\begin{array}{l}\text { Lelki } \\
\text { kiégés }\end{array}$ & Érzelmi kiégés & Szociális kiégés & $\begin{array}{c}\text { Kiégés összesitett } \\
\text { pontszám }\end{array}$ \\
\hline \multirow{5}{*}{ 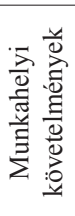 } & Összesített pontszám & 0,319 & 0,385 & 0,273 & 0,385 \\
\hline & Munkamód követelményei & 0,165 & 0,280 & N.Sz. & 0,203 \\
\hline & Mentális követelmények & N.Sz. & N.Sz. & $-0,141$ & N.Sz. \\
\hline & Érzelmi követelmények & 0,252 & 0,292 & N.Sz. & 0,237 \\
\hline & Konfliktusok & 0,319 & 0,385 & 0,273 & 0,385 \\
\hline \multirow{5}{*}{ 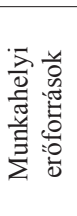 } & Összesített pontszám & $-0,456$ & $-0,600$ & $-0,401$ & $-0,575$ \\
\hline & Személyes fejlődés & $-0,306$ & $-0,273$ & $-0,348$ & $-0,359$ \\
\hline & Információ, visszajelzés & $-0,397$ & $-0,569$ & $-0,377$ & $-0,531$ \\
\hline & Munkavégzés feletti kontroll & $-0,334$ & $-0,390$ & $-0,177$ & $-0,358$ \\
\hline & Felettes támogatása & $-0,239$ & $-0,415$ & $-0,227$ & $-0,351$ \\
\hline \multicolumn{2}{|c|}{ Leterheltség pontszám } & 0,474 & 0,632 & 0,324 & 0,568 \\
\hline
\end{tabular}

Kutatásunk célja volt, hogy megvizsgáljuk, a szervezeti tényezők mely elemei kapcsolódnak legerősebben a kiégés jelenségéhez. A változók hatásának modellezésére lineáris regresszióelemzést végeztünk. A modellben a kiégés összesített pontszáma függő változóként, míg a vizsgált szervezeti tényezők független változóként szerepeltek. A független változókat három erőforrás (személyes fejlődés lehetősége, kontroll, illetve az információk és visszajelzések), valamint két követelmény (az érzelmi megterhelés és a személyes konfliktusok) alkották. Az elemezést ENTER módszerrel végeztük. Az eredményeket a 2. táblázatban foglaltuk össze.

2. táblázat. A kiégés összesitett pontszám varianciájának magyarázatához létrehozott regressziós modell tesztelésének föbb eredményei $*_{p}>0,001$

\begin{tabular}{|l|c|c|c|}
\hline \multirow{2}{*}{\multicolumn{1}{|c|}{ Változó }} & \multicolumn{3}{c|}{ Kiégés pontszám } \\
\cline { 2 - 4 } & \multicolumn{3}{c|}{ Modell } \\
\hline Személyes fejlödés lehetösége & $B$ & SE B & $\beta$ \\
\hline Munkavégzés feletti kontroll & $-0,619$ & 0,153 & $-0,195$ \\
\hline Információk és visszajelzések & $-0,343$ & 0,134 & $-0,121$ \\
\hline Érzelmi megterhelés & $-1,034$ & 0,152 & $-0,346$ \\
\hline Személyes konfliktusok & 0,478 & 0,131 & 0,170 \\
\hline $\mathrm{R}^{2}$ & 0,731 & 0,209 & 0,167 \\
\hline F-érték & & 0,401 & \\
\hline
\end{tabular}


Az adatokból leolvasható, hogy az öt változó mindegyike szignifikáns hatást gyakorol a függő változóra. Együttesen a variancia 40\%-át magyarázzák. Az erőforrások negatív, míg a követelmények pozitív összefüggést mutatnak a kiégéspontszámmal, ahogy azt az előzetes korrelációs elemzések alapján valószínüsítettük. A táblázat adataiból leolvasható, hogy az erőforrások kapcsolata a kiégéssel erőteljesebb, mint a követelményelemeké.

\section{Összegzés, következtetések}

A kiégés és azon belül a tanári kiégés problémája nemcsak személyes szinten jelent nehézséget, de érinti azokat is, akikkel a kiégés valamelyik fázisában levő személy rendszeresen érintkezik. Különösen kritikus ez a probléma a tanárok esetében, hisz a személyiségfejlődés folyamatában levő fiatalokkal dolgoznak, akikre a tanár személyisége, mentális és hangulati jellemzői jelentős hatással vannak. Az egészségügyben, illetve más veszélyeztető munkahelyeken dolgozók kiégettségnek okairól, tényezőiről viszonylag gazdag tudással rendelkezünk. Azonban a tanári kiégés vizsgálata hazánkban viszonylag ritka, ezért van jelentősége annak, hogy minél több elemét feltárjuk a kiégéshez vezető tényezőknek. Ezek közül föként a személyes szinten ható elemekre fókuszált a tavalyi évben végzett komplex kutatás (Paksi és mtsai, 2015). Saját vizsgálatunkban a szervezeti, munkahelyi tényezőket állítottuk a középpontba egy létező modell kapcsán (Demerou$t i$ és $m t s a i, 2001)$. A modell lényege, hogy nemcsak a követelményekre, a munkavégzés nehézségeire helyezi a hangsúlyt, hanem összeveti azokat az erőforrásokkal, amelyek a dolgozó számára rendelkezésre állnak a követelmények teljesítéséhez. A kiégés okát nem egyik vagy másik tényező mértékében kell keresnünk, hanem a két tényező különbsége az, ami valószínűsíti a kiégés megjelenését. A leterheltség akkor nagy, ha a követelmények nagyobbak, mint a rendelkezésre álló erőforrások.

Saját fejlesztésű mérőeszközünk segítségével ezt a leterheltségi mutatót kerestük, és elemeztük a pedagógusok válaszai alapján. Bebizonyosodott, hogy a más területekre kialakított elméleti modell a pedagógusok esetében is megállja a helyét. Eredményeink alapján úgy tünik, hogy követelmények nagyobb mértéke együtt jár a kiégés tüneteinek súlyosbodásával, míg az erőforrások a kiegyensúlyozottabb munkahelyi tapasztalatokkal hozhatók összefüggésbe. Fontos kiemelni továbbá, hogy a követelmények hatását képesek ellensúlyozni az erőforrások. Erre utalnak a két tényező különbségeként létrehozott leterheltségváltozóval kapcsolatban kapott adatok.

Kutatásunk további eredménye szerint az iskolatípus, amelyben a pedagógus dolgozik, hatással van a kiégés mértékére. E szerint a legmagasabb kiégés pontszámot a szakközépiskolákban tanítók körében találtuk. Ezt a leterheltség egy olyan jellemzőjével magyarázhatjuk, amelyet jelen vizsgálatban külön nem mértünk, ugyanakkor jelenléte egyértelmü. Nevezetesen, hogy az elvárás oldalon plusz teherként jelentkezik, hogy a szakközépiskolákban a közismereti tárgyak mellett a diákoknak a szaktárgyakból is le kell érettségizni. Ugyanakkor a tanítás sikerességének legfontosabb erőforrása a diákok motivációja, amely a szakközépiskolát választók esetében bizonyosan alacsonyabb, mint a gimnazistáknál. Így a bizonyos értelemben magasabb elvárások a másik oldalon kisebb erőforrással párosulnak.

Eltekintve az iskolatípus okozta enyhe különbségtöl, összességében elmondható, hogy a kiégés általános mértéke jelen kutatás szerint ebben a csoportban alacsonynak mondható. Ez az eredmény bár lényegében hasonló, mint a nemrégiben hazai mintán elvégzett átfogó kutatásé (Paksi és mtsai, 2015), mégis elgondolkodtató, ha összevetjük a valós tapasztalatokkal. Érdemes elgondolkodni ennek a diszkrepanciának a lehetséges magyarázatán. Habár a kérdőíves adatfelvételbe rövid idő alatt számos résztvevőt sikerült bevonnunk, a kutatás témájának jellege már önmagában szelektálhatta a résztevőket. 
Azaz, elképzelhető, hogy azok döntöttek a válaszadás mellett, akik kevésbé érintettek a kiégés kapcsán, és hajlandóak időt és energiát fordítani egy újabb nem kötelező feladatra. A jövőben érdemes lenne arra törekedni, hogy inkább teljes tantestületek bevonásával végezzünk méréseket, és ne egyedi jelentkezés vagy megkeresés alapján. Ez egyrészt növelné a kérdőív eredményeiből levonható következtetések érvényességét, másrészt lehetővé tenné az intézményi jellemzők azonosítását, és a szervezeti szintü intervenciót, az adott tantestület problémájának jellegéhez igazítva.

Kutatásunk további limitációja, hogy jelen vizsgálatba nem vontunk be egyéni személyiségjellemzőket, amelyek egy adott terheltségi mutató mellett is különbséget tehetnek a kiégés mértékében. A további kutatások során ezért tervezzük a kiégés szervezeti jellemzői mellett a megküzdési stratégiák, a mindset (szemléletmód) és más olyan individuális tényezők bevonását, amelyek protektív faktorként jelenhetnek meg a kiégés megjelenésével szemben. A szervezeti és egyéni tényezők együttes vizsgálata komplex elméleti alapot biztosíthat a hatékony kiégés prevenciós és intervenciós stratégiák kialakításához.

\section{Irodalomjegyzék}

Ahola, K. és Hakanen, J. J. (2014): Health and Burnout. In Leiter, M., Bakker, A. B. és Maslach, C. (ed.). Burnout at Work. A Psychological perspective. Psychology Press. DOI: 10.4324/978131589416

Brouwers, A., Tomic, W. és Boluijt, H. (2011): Job demands, job control, social support and self-efficacy beliefs as determinants of burnout among physical education teachers. Europe's Journal of Psychology, 7. 1. sz. 17-39. DOI: 10.5964/ejop.v7i1.103

Ceyda, G. és Sevinc, P. (2012): Determination of High Schools Organizational Climate. Procedia Social and Behavioral Sciences, 46. 2947-2950. DOI: 10.1016/j.sbspro.2012.05.595

De Caroli, M. E. és Sagone, E. (2012). Professional Self Representation and Risk of Burnout in School Teachers. Procedia - Social and Behavioral Sciences, 46. 5509-5515. DOI: 10.1016/j.sbspro.2012.06.466

Demerouti, E., Bakker, A. B., Nachreiner, F., Schaufeli, W. B. (2001): The job demands-resources model of burnout. Journal of Applied Psychology, 86. 3. sz. 499-512. DOI: 10.1037//0021-9010.86.3.499

Farber, B. A. (1991): Crisis in education: Stress and burnout in the American teacher. Jossey-Bass, San Francisco.

Fernet, C., Guay, F., Senécal, C. és Austin, S. (2012): Predicting intraindividual changes in teacher burnout: The role of perceived school environment and motivational factors. Teaching and Teacher Education, 28. 4. sz. 514-525.

DOI: $10.1016 /$ j.tate.2011.11.013

Freudenberger, H. J. (1974): Staff Burn-Out. Journal of Social Issues, 30. 1. sz. 159-165.

DOI: 10.1111/j.1540-4560.1974.tb00706.x

Glass, D. C. és McKnight, J. D. (1996): Percieved control, depressive symptomagology, and professional burnout: A review of the evidence. Psychology and Health, 11. 1. sz. 23-48.

DOI: $10.1080 / 08870449608401975$

Hakanen, J. J., Bakker, A. B. és Schaufeli, W. B. (2006): Burnout and work engagement among teachers. Journal of School Psychology, 43. 6. sz. 495-513. DOI: 10.1016/j.jsp.2005.11.001

Hare, J., Pratt, C. C. és Andrews, D. (1988): Predictors of burnout in professional and paraprofessional nurses working in hospitals and nursing homes. International Journal of Nursing Studies, 25. 2. sz., 105-115. DOI: 10.1016/00207489(88)90078-8

Jagodics, B. és Szabó, É. (2014): Job demands versus resources: workplace factors related to teacher burnout. Theory and Research in Education, 9. 4. sz. 377-390.

Kalimo, R. és Hakanen, J. (2000): Työuupumus [Work and Health in Finland: Burnout]. In S. Virtanen (ed.): Työjaterveys Suomessa v. 2000. Työterveyslaitos, Helsinki. 119-126.

Karasek, R. A. (1979): Job Demands, Job Decision Latitude, and Mental Strain: Implications for Job Redesign. Administrative Science Quarterly, 24. 2. Sz. 285-309. DOI: 10.2307/2392498

Lackritz, J. R. (2004): Exploring burnout among university faculty: incidence, performance and demographic issues. Teaching and Teacher Education, 20. 7. sz. 713-729.

DOI: $10.1016 /$ j.tate.2004.07.002

Maslach, C. (1982): Burnout: The cost of caring. Prentice-Hall, New York.

Maslach, C. és Goldberg, J. (1998): Prevention of burnout: New perceptions. Applied \& Preventive Psychology, 7. 1. sz. 63-74. DOI: 10.1016/s09621849(98)80022-x 
Szabó Éva - Jagodics Balázs: Erőforrások és követelmények

Maslach, C., Jackson, S. E. és Leiter, M. P. (1996): The Maslach Burnout Inventory. 3rd ed. Consulting Psychologists Press, Palo Alto, CA.

Orosz G. és Karsai N. F. (2012): Az egyetemi oktatók lelkesedésének és a hallgatók csalásának összefüggései. Iskolakultúra, 9. 3-11.

Özer, N. és Beycioglu, K. (2010): The relationship between teacher professional development and burnout. Procedia Social and Behavioral Sciences, 2. 2. sz. 4928-4932. DOI: 10.1016/j.sbspro.2010.03.797

Paksi B., Veroszta Zs., Schmidt A., Magi A., Vörös A., Endrödi-Kovácsi V., Felvinczi K. (2015): Pedagógus - Pálya - Motiváció - Egy kutatás eredményei. Oktatási Hivatal, Budapest.

Petróczi E. (2007): Kiégés - elkerülhetelen? Eötvös Kiadó, Budapest.

Price, D., \& Murphy, P. (1984): Staff burnout in the perspective of grief theory. Death Education, 8, 47-58. DOI: 10.1080/07481188408251381

Pruyser, P. (1984): Existentail impact of professional exposure to life-threatening or terminal illness. Bulletin of the Menninger Clinic, 48. 357-367.
Schein, E. H. (1997): Organizational Culture and Leadership. Jossey-Bass Publishers, San Fransisco.

Schreiber, J. B., Stage, F. K., King, J., Nora, A. és Barlow, E. A. (2006): Reporting structural equation modelling and confirmatory factor analysis results: A review. The Journal of Educational Research, 99. 6. sz.

Skaalvik, E. M. és Skaalvik, S. (2009): Does school context matter? Relations with teacher burnout and job satisfaction. Teacher and Teaching Education, 25. 3. sz. 518-524. DOI: 10.1016/j.tate.2008.12.006

Tanhan, F. és Cam, Z. (2011): The relation between mobbing behaviors teachers in elementary schools are exposed to and their burnout levels. Procedia Social and Behavioral Sciences, 15. 2704-2709. DOI: 10.1016/j.sbspro.2011.04.174

Tatar, M. és Yahav, V. (1999): Secondary school pupils' perceptions of burnout among teachers. British Journal of Educational Psychology, 69. 4. sz. 457-468. DOI: 10.1348/000709999157824 